\title{
Carbohydrates Components of Some Italian Local Landraces: Garlic (Allium sativum L.)
}

\author{
Silvia Lisciani ${ }^{1}$, Loretta Gambelli ${ }^{1}$, Alessandra Durazzo ${ }^{1, *}$, Stefania Marconi ${ }^{1}$, \\ Emanuela Camilli ${ }^{1}$, Cecilia Rossetti ${ }^{1}$, Paolo Gabrielli ${ }^{1}$, Altero Aguzzi ${ }^{1}$, Olindo Temperini ${ }^{2}$ and \\ Luisa Marletta ${ }^{1}$ \\ 1 Consiglio per la Ricerca in Agricoltura e L'analisi Dell'economia agraria-Centro di ricerca CREA-Alimenti e \\ Nutrizione, Via Ardeatina 546, 00178 Rome, Italy; silvia.lisciani@crea.gov.it (S.L.); \\ loretta.gambelli@crea.gov.it (L.G.); stefania.marconi@crea.gov.it (S.M.); emanuela.camilli@crea.gov.it (E.C.); \\ rossetti.cecilia@gmail.com (C.R.); paolo.gabrielli@crea.gov.it (P.G.); altero.aguzzi@crea.gov.it (A.A.); \\ luisa.marletta@crea.gov.it (L.M.) \\ 2 Dipartimento di Scienze Agrarie e Forestali (DAFNE), Università degli Studi della Tuscia, \\ 01100 Viterbo, Italy; olindotemperini@gmail.com \\ * Correspondence: alessandra.durazzo@crea.gov.it; Tel.: +39-06-5149-4430
}

Received: 11 September 2017; Accepted: 22 October 2017; Published: 24 October 2017

\begin{abstract}
Garlic is one of the most widespread and ancient medicinal plants. Its health benefits are due to its chemical components, and among these is carbohydrate, whose characteristics have been so far little investigated. The aim of this study is to typify the various components of carbohydrate (starch, individual sugars, fructans, and total dietary fibre) in four commonly consumed "Italian local landraces": Bianco Piacentino, Rosso di Castelliri, Rosso di Sulmona, Rosso di Proceno, which are grown in two different geographical areas—Viterbo and Alvito—under the same agronomic conditions. This study will also evaluate how genotype and the cultivation area can affect the profile of the carbohydrate components of these landrace strains. Regarding unavailable carbohydrates, all of the varieties showed appreciable contents of fructans, the most representative component, which ranged from 45.8 to $54.4 \mathrm{~g} / 100 \mathrm{~g}$ d.w. In contrast, total dietary fibre values varied from 9.1 to $13.1 \mathrm{~g} / 100 \mathrm{~g}$ d.w. in Rosso di Castelliri and Bianco Piacentino, respectively, which are both grown in Viterbo. As for starch, only some traces were found, while the amount of total sugars ranged between 2.12 and $3.27 \mathrm{~g} / 100 \mathrm{~g}$ d.w., with higher levels of sucrose. Our findings could provide important information that may be adopted to enhance and promote the quality of some local Italian garlic landraces through highlighting the influence that the cultivar and the environmental conditions can have on carbohydrates components.
\end{abstract}

Keywords: Italian garlic; carbohydrates; fructans; dietary fibre; soluble sugars; cultivar; environmental conditions

\section{Introduction}

Garlic (Allium Savitum L.) is a vegetable bulb native to central Asia and belonging to the plant family Amaryllidaceae [1]. It is widely used in gastronomy for dressing and spicing dishes. Moreover, it has been used as a medicinal plant since ancient times, and it is still being employed in folk medicine all over the world. According to Food and Agriculture Organization of the United Nations (FAO) [2], its global production is close to 15 million tons, with China as world's first export and production country. Between 2008 and 2013, China's shipments increased from 13 to 18 million tons; in second place, just behind, are Spain and Argentina, while the Netherlands play a redistribution function of the product from other countries (China and Argentina), and Italy ranks fifth [3]. It has been observed that garlic production has not significantly decreased over the last decades, thanks to the availability 
of several new garlic-based products on the gastronomic market (dressings, pickled garlic, seasonings, powders, oil, etc.). Despite this, a lot of Italian varieties of this bulb, although known and appreciated in many national and international dishes, risk disappearing.

Although Italian cuisine is known for its variety and regional diversity, it includes garlic among its main ingredients, which is used to enhance the flavour of many foods and traditional and local recipes. Garlic is grown all over Italy, and its most common landraces mainly belong to two types: white garlic and pink garlic. They are characterised, respectively, by white-silvered and pinkish-purple skin. In particular, some Italian local landraces originally produced in a limited geographical area have spread throughout the country because of their organoleptic properties and long tradition [4].

Numerous studies have investigated the health benefits related to garlic consumption, which include [5-12]: the reduction of risk factors for cardiovascular diseases and cancer, the stimulation of the immune response, the antimicrobial effects [13,14], the invigorating action, the resistance to various stresses, and the potential anti-aging effects $[13,15-17]$. These physiological properties depend both on the characteristic profile of the bioactive components [18] of garlic and their combined action; the peculiar components of garlic are volatile sulphur compounds, such as sulfoxides and thiosulfinates, which are known not only for their beneficial properties, but also mostly for their typical smell and taste [19-22].

Among the numerous health benefits associated with the consumption of garlic, our attention in particular, is towards the characterization of carbohydrates components, which are related to the prebiotic activity of this bulb. This function is due to its high content of fructans and dietary fibre [8,23]. Several researchers have investigated the physiological role of fructans in plants [24,25]; fructans are fructose polymers that provide the short-term energy storage in many plant species [26]. The global distribution of fructan-accumulating plants shows that they are particularly copious in temperate zones, while they are almost absent in tropical regions, or during seasonal drought or frost $[27,28]$. The amount of fructans, as for other metabolites, is strongly influenced by genetic and environmental factors, including: growth factors such as light, temperature, humidity, and fertilizers; damages caused by microorganisms and insects, stress induced by UV radiation, heavy metals, and pesticides [29].

According to the type of linkage, fructans are classified into three groups of compounds: inulin, levan, and graminan $[8,30,31]$. Inulin-type compounds include fructans with a short chain composed by 2-9 units or degree of polymerization (DP), which are generally named fructo-oligosaccharides (FOS), and with long-chain ones (DP > 10), called inulins [4,32,33]. In this study, we include both FOS and inulins within the term "fructans".

Because of the $\beta(2 \rightarrow 1)$ linkage of fructose monomers, fructans cannot be digested by the intestinal enzymes; they are defined, indeed, as "non-digestible/unavailable" carbohydrates. However, a regular consumption of such non-digestible polysaccharides has positive effects on human health [34]; in fact, their fermentation takes place in the colon, and this activity is well recognized to play an essential role in the improvement of health and, as a consequence, in the reduction of the risk of diseases. Even though fructans belong to the dietary fibre complex group because they contribute to increasing the water content of the stools and to improving bowel habits [35], they also, however, show some specific fermentative properties that are different from those attributed to dietary fibre. Therefore, fructans may contribute significantly to a well-balanced diet by intensifying and amplifying the beneficial effects of dietary fibre and by influencing several gastrointestinal and systemic functions [36]. In the colon, the fermentation of inulin-type fructans is fast, and based on three main sequential phases: the production of short-chain fatty acids (SCFA) that reduce the intestinal $\mathrm{pH}$; the reduction of putrefactive substances in the intestine, and finally, the increase of the bifidobacteria population, which does not alter the total bacteria levels [8,37-39].

Inulin and FOS are the most studied and well-known prebiotics, because they offer an interesting and remarkable combination of nutritional and technological properties for the food industry. Indeed, interest in these carbohydrates is growing worldwide, because it has been recognized that they 
can change the composition of the gut microflora by increasing the number of health-promoting bacteria [39].

Although not all of the fibre is prebiotic, some of its digestive functions that produce health benefits have been well defined and characterised: it increases the viscosity of the stomach contents, reduces the intestinal transit time, and enhances the bulk of the food mass [40]. These compounds are catching researchers' attention for their health-promoting effects, to the point that they are gradually being added to a wider variety of food products as fortification agents, and are being increasingly used as the main components in dietary supplements [28,41]. However, recent researches have emphasized that particular attention must be paid to consumers with problems of dietary intolerances to fructans and fermentable oligosaccharides, disaccharides, monosaccharides, and polyols (FODMAPs) [42].

Currently, few studies have provided data about the content of fructans in garlic and, in particular, specific information on the chemical characteristics of Italian varieties of garlic are needed. Some researchers have evaluated the phytochemical compounds of these garlic cultivars by determining the content of carotenoids, flavonoids, vitamin C, and the total antioxidant capacity [43].

At present, the main Italian Food Composition Database [44] mostly contains average values on the nutritional composition of plant foods; while information available for single varieties is currently lacking. The characterisation of the nutrient profile of the different landraces is reported in scientific publications or in limited and specific databases created to promote and preserve the nutritional characteristics of some national traditional foodstuffs [45].

This study is aimed at estimating the carbohydrate components of four Italian landraces of garlic, which are all qualified on the national market, and some are enrolled in the Italian Register of the varieties. This work is addressing to: valorise and promote local products with a long tradition by preserving and protecting their identity; analyse some chemical characteristics for a better understanding of their nutritional role; and verify possible influences exerted by the cultivar and environmental factors on the qualitative properties of garlic.

Furthermore, we propose and suggest the identification of potential genotypes, for more interesting uses for prebiotic sources addressing nutraceutical needs.

\section{Materials and Methods}

\subsection{Samples}

Four Italian landraces of Allium sativum L.-Bianco Piacentino, Rosso di Castelliri, Rosso di Sulmona, and Rosso di Proceno-that were cultivated at two locations (Viterbo and Alvito) under the same growing conditions, were investigated. In Table 1, we reported the basic information and the main descriptors of morphological characteristics.

Table 1. Main descriptors of morphological characteristics.

\begin{tabular}{ccccc}
\hline & Bianco Piacentino & Rosso di Castelliri & Rosso di Sulmona & Rosso di Proceno \\
\hline $\begin{array}{c}\text { outer skin colour of } \\
\text { compound bulb }\end{array}$ & white silvered & white & cream & cream \\
\hline $\begin{array}{c}\text { skin colour of the } \\
\text { cloves }\end{array}$ & white & red purple & dark red & red \\
\hline $\begin{array}{c}\text { shape of mature dry } \\
\text { bulbs }\end{array}$ & flat globe & ovate & broad oval & broad oval \\
\hline $\begin{array}{c}\text { regular two-fan } \\
\text { groups }\end{array}$ & $\begin{array}{c}\text { regular } \\
\text { multi-cloved radial }\end{array}$ & irregular & $\begin{array}{c}\text { regular } \\
\text { multi-cloved radial }\end{array}$ \\
\hline flavour & pungent & pungent and spicy & spicy & $\begin{array}{c}\text { persistent, strong, } \\
\text { and spicy }\end{array}$ \\
\hline
\end{tabular}


Two of them enrolled in the "National Register of horticultural varieties" (Rosso di Sulmona e Bianco Piacentino) and the ecotype Bianco Piacentino was the only garlic waiting for the Protected Geographical Indication (PGI) trademark; Rosso di Castelliri and Rosso di Proceno cultivars were part of the "Regional Register of indigenous genetic resources of agricultural interest at risk of erosion". They were cultivated and harvested in the period between June and early July.

For Bianco Piacentino, a medium-late cultivar, maturity starts between 20 June and 15 July, and the harvest from 15 to 30 July, while the harvest time of Rosso di Castelliri takes place in the first fifteen days of June. Rosso di Sulmona is an early-medium maturing garlic (around 20-30 June), and for Rosso di Proceno, harvest time is in July (Figure 1).

Currently, all of the four varieties, which were identified for their geographic origin, are the most widespread in Italy, and grown in many geographic areas throughout the country. All of the samples studied were cultivated in three parcels of two different areas in the Lazio region using the same technical-agronomic trail, as shown in Table 2.

Crop density was 18.18 (plants $/ \mathrm{m}^{2}$ ). The spacing between rows was $0.55 \mathrm{~m}$, and the distance between plants within the row was $0.20 \mathrm{~m}$. The experimental protocol consisted of split parcels with four replicates. Each elemental parcel was $4 \mathrm{~m}^{2}$, with six four-meter rows containing 240 cloves. The linear meters for each parcel were 24 . The total number of bulbs and cloves per cultivar were 240 and 1960, respectively. The soil in Viterbo was muddy and sandy with the following characteristics: pH 6.6, total N 0.09\% d.w. soil, exchangeable P 33 ppm, exchangeable K 421 ppm, $\mathrm{CaCO}_{3} 5.1 \%$ d.w. soil; the soil of Alvito was loamy and clayey, with following parameters: $\mathrm{pH} 7.7$, Total $\mathrm{N} 0.20 \%$ d.w. soil, exchangeable P 78 ppm, exchangeable $\mathrm{K} 342$ ppm, $\mathrm{CaCO}_{3} 11.2 \%$ d.w. soil.

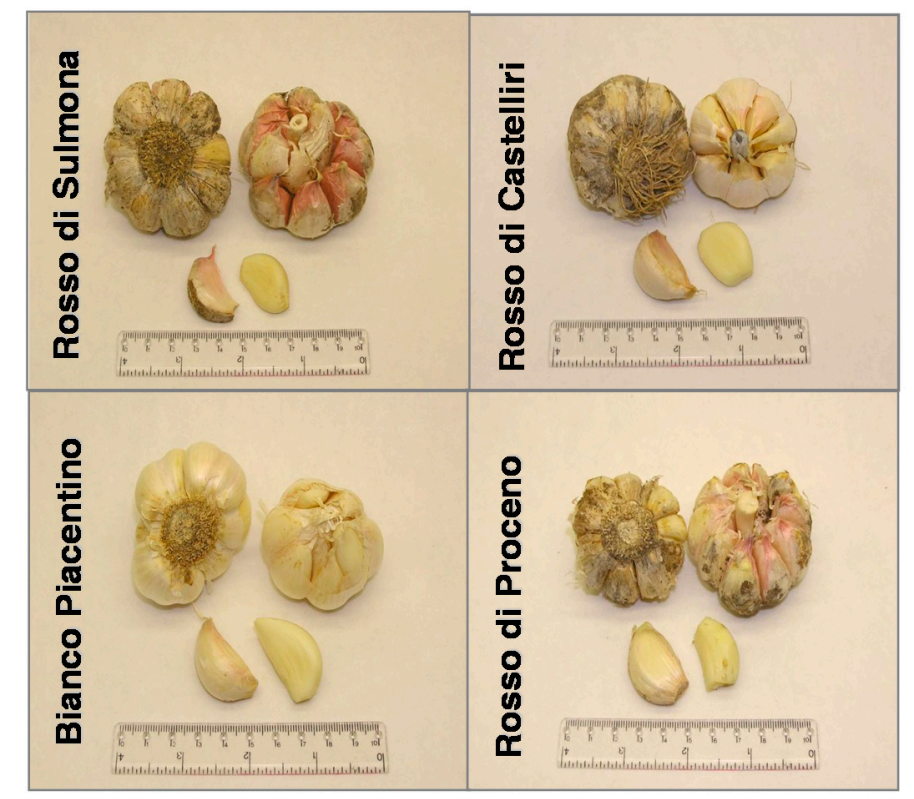

Figure 1. Photo of Bianco Piacentino, Rosso di Castelliri, Rosso di Sulmona, and Rosso di Proceno samples.

The climatic conditions observed in the graphs showed a similar trend; in the area of Alvito, a greater rainfall was reported, but its effects were not so significant to the point of affecting the production or growth of the garlic. 
Table 2. Agronomic/Technical trail of garlic production.

\begin{tabular}{|c|c|}
\hline \multicolumn{2}{|c|}{ Agronomic Trail } \\
\hline Crop density (plants $/ \mathrm{m}^{2}$ ) & 18.18 \\
\hline Spacing between rows (m) & 0.55 \\
\hline Distance (between plants) within the row (m) & 0.10 \\
\hline Experimental protocol/design & Split parcels \\
\hline Replicates & 4 \\
\hline $\begin{array}{l}\text { Elemental parcel }\left(\mathrm{m}^{2}\right) \\
\text { - raw (number) } \\
\text { - raw (lenght in m) }\end{array}$ & $\begin{array}{c}11.00(4 \times 2.75) \\
6 \\
4 \\
\end{array}$ \\
\hline Linear meters for parcel & 24 \\
\hline Cloves for elemental parcel & 240 \\
\hline Total cloves for each variety (number) & 1920 \\
\hline Total bulbs for each variety (number) & 240 \\
\hline Implant date & $26-27 / 11$ \\
\hline Planting & The cloves must be buried $4-5 \mathrm{~cm}$ deep \\
\hline Basal dressing $(\mathrm{kg} / \mathrm{ha})$ & $\begin{array}{l}250 \text { (potassium sulphate) } \\
250 \text { (DAP 18/46) }\end{array}$ \\
\hline $\begin{array}{l}\text { Top dressing }(\mathrm{kg} / \mathrm{ha}) \\
\text { - in the first decade of March } \\
\text { - in the second decade of April }\end{array}$ & $\begin{array}{l}150 \text { (ammonium nitrate) } \\
250 \text { (ammonium nitrate) }\end{array}$ \\
\hline Irrigation (400 m³ /intervention) & no irrigation was carried out \\
\hline Antiparasitic treatment (number) & 1 (melody compact -Iprovalicarb + oxychloride-) \\
\hline Antiparasitic inspection (number) & $\begin{array}{l}6 \text { (copper-based products -bordeaux mixture and } \\
\text { copper oxychloride- in spring) }\end{array}$ \\
\hline Pest check (L/ha) & $\begin{array}{l}\text { 3-Stomp-Pendimetalin based in pre-emergency } \\
\text { 1.5-Setossidim in post-emergency }\end{array}$ \\
\hline Fertilisation Unit for proposed technique & $\begin{array}{c}143 \mathrm{~N} \\
115 \mathrm{P} \\
125 \mathrm{~K} \\
44 \mathrm{~S} \\
3 \mathrm{Mg}\end{array}$ \\
\hline Fertilisation Unit for conventional technique & $\begin{array}{l}97 \mathrm{~N} \\
115 \mathrm{P} \\
44 \mathrm{~S}\end{array}$ \\
\hline
\end{tabular}

The biometric parameters of 12 samples for each ecotype and for each cultivation area were examined for a total of 96 bulbs. Samples, once in the lab, were weighed, measured, and deprived of the outer skin; then, individual cloves, evaluated randomly, were counted, weighed, and peeled. For each ecotype and for every cultivated area, a representative sample of garlic was prepared; each pool, then, was homogenised and analysed for the moisture content, frozen at $-30{ }^{\circ} \mathrm{C}$ and then lyophilised, for subsequent analyses.

The termo-pluviometric parameters during the whole garlic production were shown in Figure 2. 


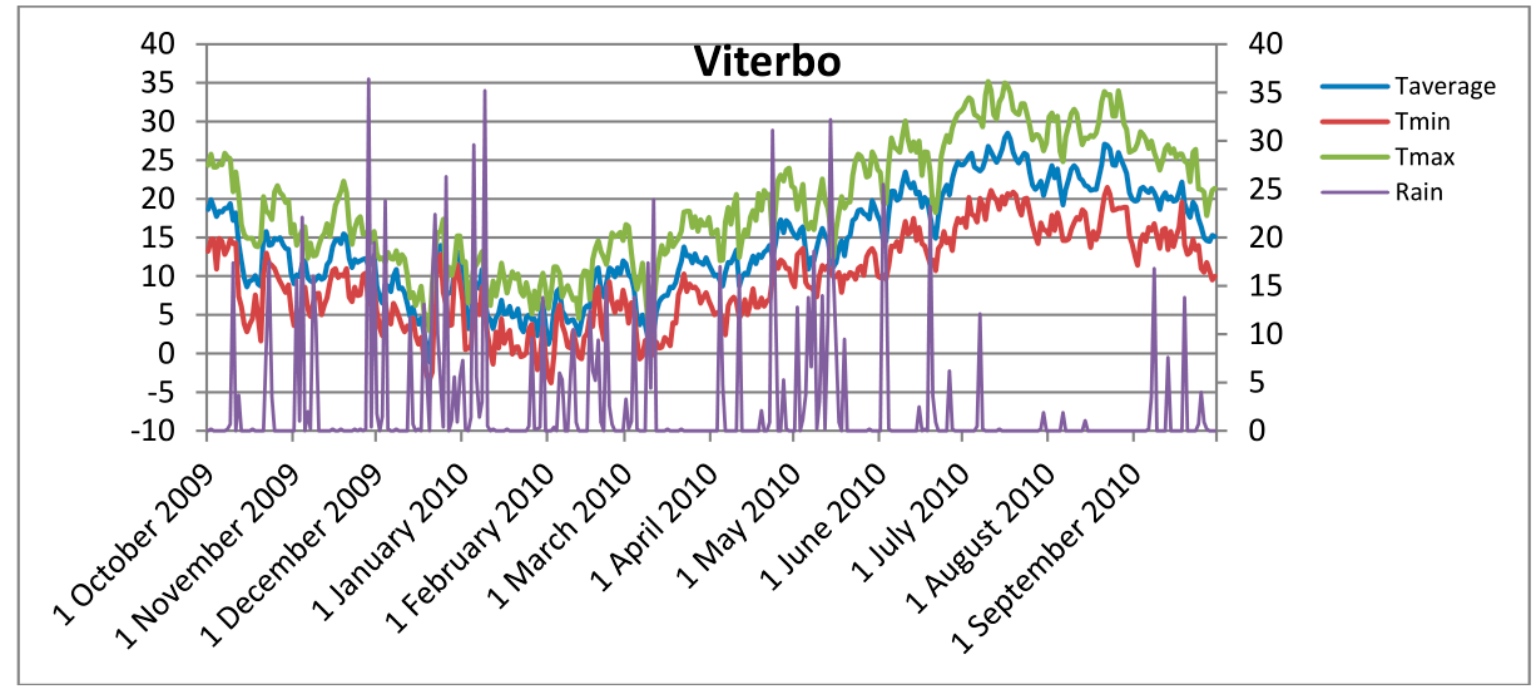

(a)

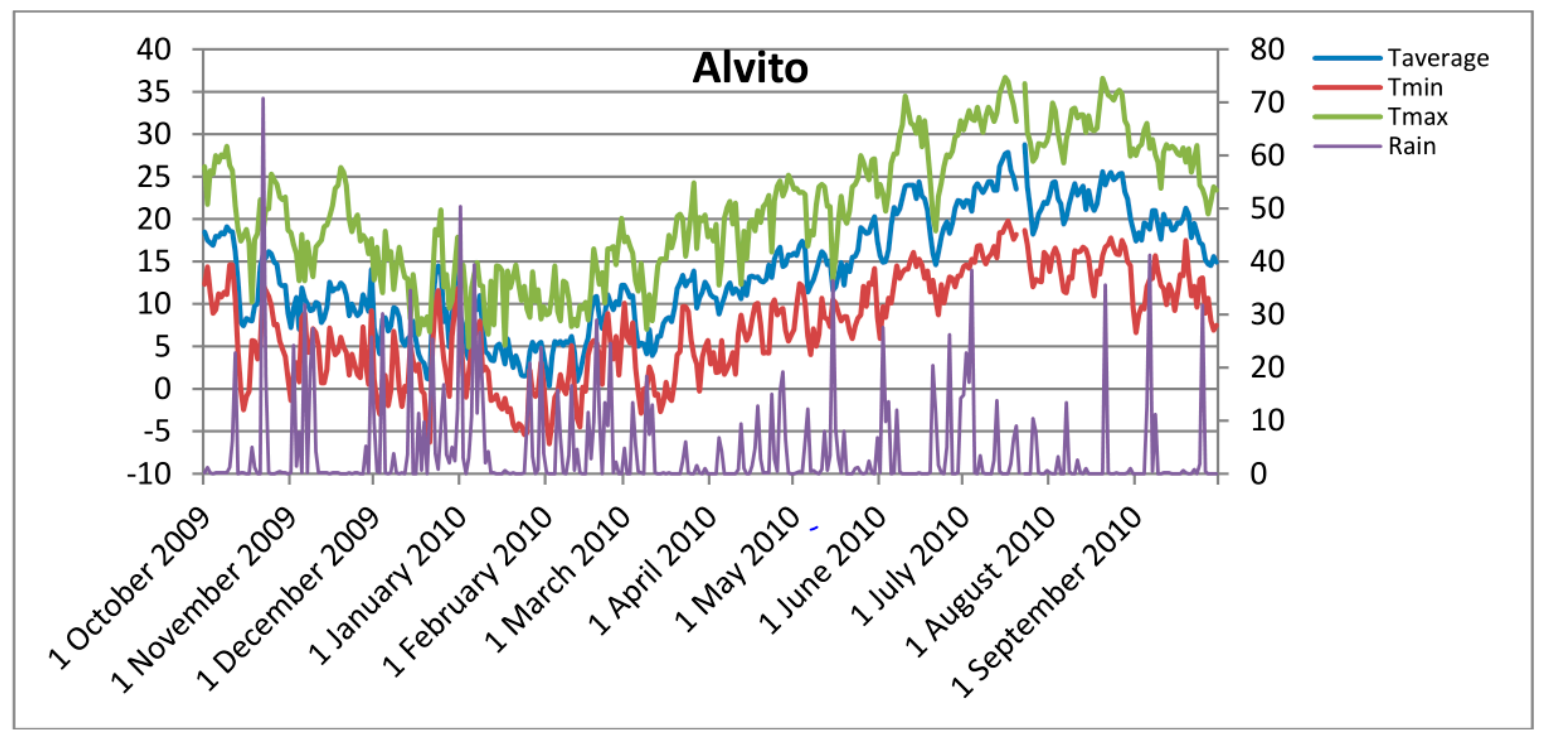

(b)

Figure 2. The termo-pluviometric parameters for the two geographical areas of (a) Viterbo and (b) Alvito, monitored during the year of production.

\subsection{Chemicals and Standards}

Reagents and standards (fructose, glucose, and sucrose) were purchased from Sigma-Aldrich Srl (Milan, Italy), Extrasynthese (Genay, France), Carlo Erba (Milan, Italy), J.T. Baker (Deventer, Holland) and BDH Laboratory Supplies (Poole, UK), and were of the analytical grade purity. Double-distilled water (Millipore, Milan, Italy), purified with a Milli-QTM system, was used throughout the study.

\subsection{Analyses}

All analyses were carried out in triplicate according to official methods [46], and the results were expressed as mean $\pm \mathrm{SD}$. 


\subsubsection{Available Carbohydrates}

Starch

Total starch was analysed using the Megazyme Total Starch Assay kit (AOAC Method 996.11 and AACC Method 76.13; Megazyme International Ireland Ltd., Wicklow, Ireland), based on the enzymatic hydrolysis method described by McClearly et al. [47]. Samples were pre-extracted with $80 \%$ of ethanol to remove glucose; the complete starch solubilisation was achieved by heating up the samples in presence of thermostable alpha-amylase, followed by hydrolysis to glucose with amyloglucosidase. Maltodextrins were hydrolysed to glucose with glucoamylase and the glucose produced was oxidised to d-gluconate with the release of one mole of hydrogen peroxide $\left(\mathrm{H}_{2} \mathrm{O}_{2}\right)$; this was quantitatively measured in a colourimetric reaction employing peroxidase and the production of a quinoneimine dye. The starch content was finally determined as liberated glucose chemically transformed to exhibit absorbance at $510 \mathrm{~nm}$. The analysis procedure was allowed by standard control: regular maize starch.

\section{Soluble Sugars}

Soluble sugars (glucose, fructose, and sucrose) were determined by anion exchange chromatography technique using a DIONEX (ion chromatograpy system, mod ICS 5000, Sunnyvale, CA, USA) equipped with GP50 gradient pump, amperometric detector (HPAE-PAD) and column Carbopac PA1 $(250 \times 4 \mathrm{~mm})$ (Dionex corporation, Sunnyvale, CA, USA); the mobile phase was $160 \mathrm{~mm} \mathrm{NaOH}$, and the flow rate was kept constant at $1.0 \mathrm{~mL} / \mathrm{min}[48,49]$. Sugars were extracted from garlic using distilled water (20 min in sonicator). Certified material LGC-7103 was analysed as the control of accuracy of the analysis of soluble sugars.

\subsubsection{Unavailable Carbohydrates}

\section{Fructans (FOS)}

The fructan content was determined using the Megazyme Fructan HK Assay kit (AOAC Method 999.03 and AACC Method 32.32; Megazyme International Ireland Ltd., Wicklow, Ireland), based on the enzymatic hydrolysis method described by McClearly and Blakeney [50]. The samples were treated with hot water to dissolve the fructan components. Aliquots, instead, were treated with specific enzymes to hydrolyse the sucrose to glucose, and the fructose and the starch to glucose: sucrose was hydrolysed by a specific sucrase enzyme that has no action on the lower degree of polymerisation [51]. Starch and maltodextrins were hydrolysed to maltose and maltotriose by pullulanase and $\beta$-amylase, and these oligosaccharides were then hydrolysed to d-glucose by maltase.

Then, all of the reducing sugars were reduced to sugar alcohols using a treatment based on alkaline borohydride. After this procedure, fructans were hydrolysed to fructose and glucose ultrapure exo-inulinase and endoinulinase [51], then were measured by para-hydroxybenzoic acid hydrazide method for reducing sugars [52]. The analysis procedure was allowed by standard control: dahlia fructan freeze-dried in the presence of $\alpha$-cellulose.

\section{Total Dietary Fibre (TDF)}

The total dietary fibre was evaluated using the enzymatic-gravimetric method described by AOAC 985.29 [47]. Duplicates of freeze-dried samples were treated with a sequential enzymatic digestion by heat stable ( $\alpha$-amylase, protease, and amyloglucosidase) to remove starch and protein. Samples were heated at $100{ }^{\circ} \mathrm{C}$ with heat stable $\alpha$-amylase to give gelatinisation, hydrolysis, and depolymerisation of starch; then, samples were incubated at $60^{\circ} \mathrm{C}$ with protease to solubilise and depolymerise proteins, and with amyloglucosidase to hydrolyse starch fragments to glucose. Ethanol was added to precipitate the soluble dietary fibre; the residue was then filtered, washed with ethanol, dried, and weighed. One duplicate was analysed for protein, and the other was incubated at $550{ }^{\circ} \mathrm{C}$ 
to determine ash. Total dietary fibre was calculated as a weight of the residue less the weight of the protein and ash.

\subsection{Quality Assurance Procedures}

The quality control of analytical procedures was performed through a precise and accurate execution of the methods. Appropriate reagents, equipment, and suitable tests (e.g., system suitability testing) were used during the analysis to check the analytic reproducibility and the validity of the result; the standard deviation (SD) of all of the analytical values was calculated; the accuracy of the procedure was established by the analysis of certified material.

\subsection{Statistical Analysis}

All the analyses were performed in triplicate, and data were expressed as means \pm standard deviation (SD). The statistical analysis was performed using Statistica for Windows (Statistical package; release 4.5; StatSoft Inc., Vigonza, PD, Italy). One-way Analysis of Variance (ANOVA) was done to determine the statistical significance. A $p$-value of less than 0.05 was taken as significant. The Student's $t$-test was used to compare the cultivation areas for each cultivar.

\section{Results and Discussion}

An analysis of the biometric parameters was carried out on each variety in order to define the morphological differences of local landraces and possible differences due to the cultivation area. The results showed significant differences between the average weights of bulbs from the two geographic areas, except for the Rosso Proceno. The average weights of samples from Alvito ( $40 \mathrm{~g} \pm 6.2$ ) were mostly higher than those of samples grown in Viterbo ( $33 \mathrm{~g} \pm 2.9$ ); Rosso di Castelliri landrace showed the largest bulbs (weight $47.1 \mathrm{~g}$ and size $5.7 \mathrm{~cm}$ ), and of those grown in Alvito, the highest values were for cloves weight, as shown in Table 3. The number of cloves in a garlic bulb resulting from both cultivar and cultivation area ranged from 9 to 16 . The weights of bulb and cloves are similar to the those reported by Fanaei et al. [53], who analysed different garlic genotypes in the range of 24-50 $\mathrm{g}$ and 2.93-5.2 g, respectively; the same authors also observed a number of cloves for bulb from 6 to 11. These variations might be due to the genetic variations among garlic cultivars and their ability for exploiting the environmental sources, particularly light, $\mathrm{CO}_{2}$, water and nutrients as underlined by several authors $[53,54]$, as well as cultivation conditions $[55,56]$. Moreover, Dhakulkar et al. [55] studied the effect of spacing and clove size on the yield and quality of garlic, and reported that the weight of bulbs varied from 12.05 to $15.66 \mathrm{~g}$, and the number of cloves per bulb varied from 16.70 to 21.50. A recent study of Sachin et al. [56] marked how the application of organic and inorganic sources of nitrogen significantly affected the quality attributes of garlic.

Table 3. Biometric parameters of four garlic ecotypes.

\begin{tabular}{cccccccc}
\hline \multicolumn{3}{c}{ Bulbs } & \multicolumn{3}{c}{ Cloves } \\
\hline & & $\begin{array}{c}\text { Horizontal } \\
\text { Section (cm) }\end{array}$ & Weight (g) & Waste (\%) & Number n & Weight (g) & Waste (\%) \\
\hline Bianco & Viterbo & $4.0-5.0$ & $26.6-50.9$ & $5-11$ & $12-21$ & $1.8-4.1$ & $5-11$ \\
Piacentino & Alvito & $4.0-6.0$ & $25.7-62.0$ & $1-3$ & $7-20$ & $1.9-5.6$ & $1-9$ \\
\hline Rosso di & Viterbo & $3.8-6.3$ & $17.2-47.7$ & $5-8$ & $6-13$ & $2.0-5.0$ & $3-12$ \\
Sulmona & Alvito & $4.5-6.0$ & $26.8-54.3$ & $2-4$ & $10-15$ & $2.6-3.7$ & $2-3$ \\
\hline Rosso di & Viterbo & $4.0-5.5$ & $25.3-38.6$ & $3-12$ & $7-11$ & $3.1-6.3$ & $3-10$ \\
Castelliri & Alvito & $5.1-6.4$ & $33.8-62.0$ & $2-3$ & $9-15$ & $3.5-7.3$ & $2-7$ \\
\hline Rosso di & Viterbo & $3.9-5.5$ & $22.7-42.5$ & $3-15$ & $6-10$ & $2.7-4.7$ & $5-9$ \\
Proceno & Alvito & $3.5-5.7$ & $18.0-47.6$ & $2-4$ & $7-15$ & $2.0-5.9$ & $2-7$ \\
\hline
\end{tabular}


The total carbohydrate content in the four local landraces grown in the two selected production areas and analysed in this study showed values ranging from 22.8 to $26.2 \mathrm{~g} / 100 \mathrm{~g}$ of fresh edible portion. The percentage distribution of the different carbohydrate fractions was reported in Figure 3: on average, $78 \%$ were represented by fructans, $18 \%$ by dietary fibre, and $4 \%$ by total soluble sugars, with $0 \%$ by starch content.

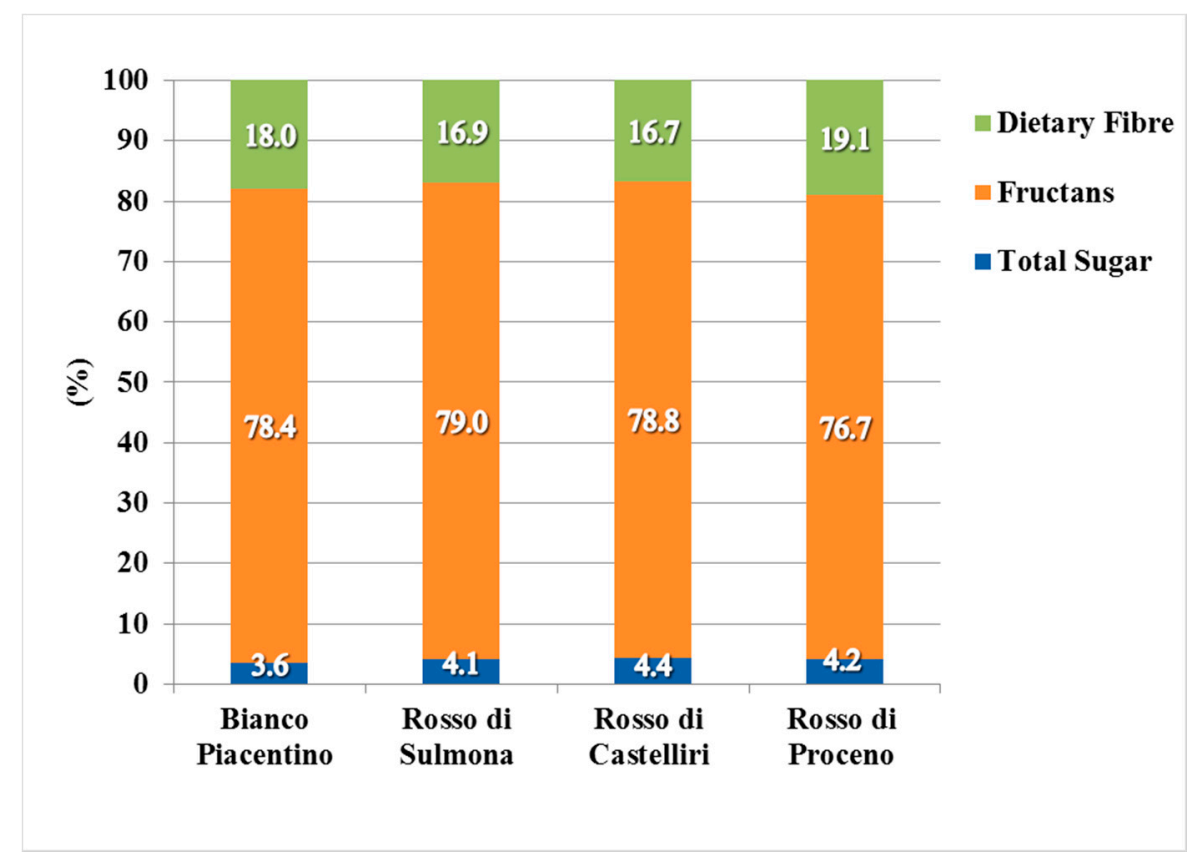

Figure 3. Percentage distribution of the different carbohydrate fractions in four garlic landraces.

The characterisation of the individual soluble sugars of four Italian local landraces cultivated at two locations was shown in Figure 4, where glucose, fructose, and sucrose contents were reported. It appeared clear that the major fraction was represented by sucrose, which comprised $94 \%$ of total sugars; furthermore, for each sugar, cultivars grown in Viterbo showed slightly higher values than those of samples coming from Alvito. However, the differences found were not statistically significant.

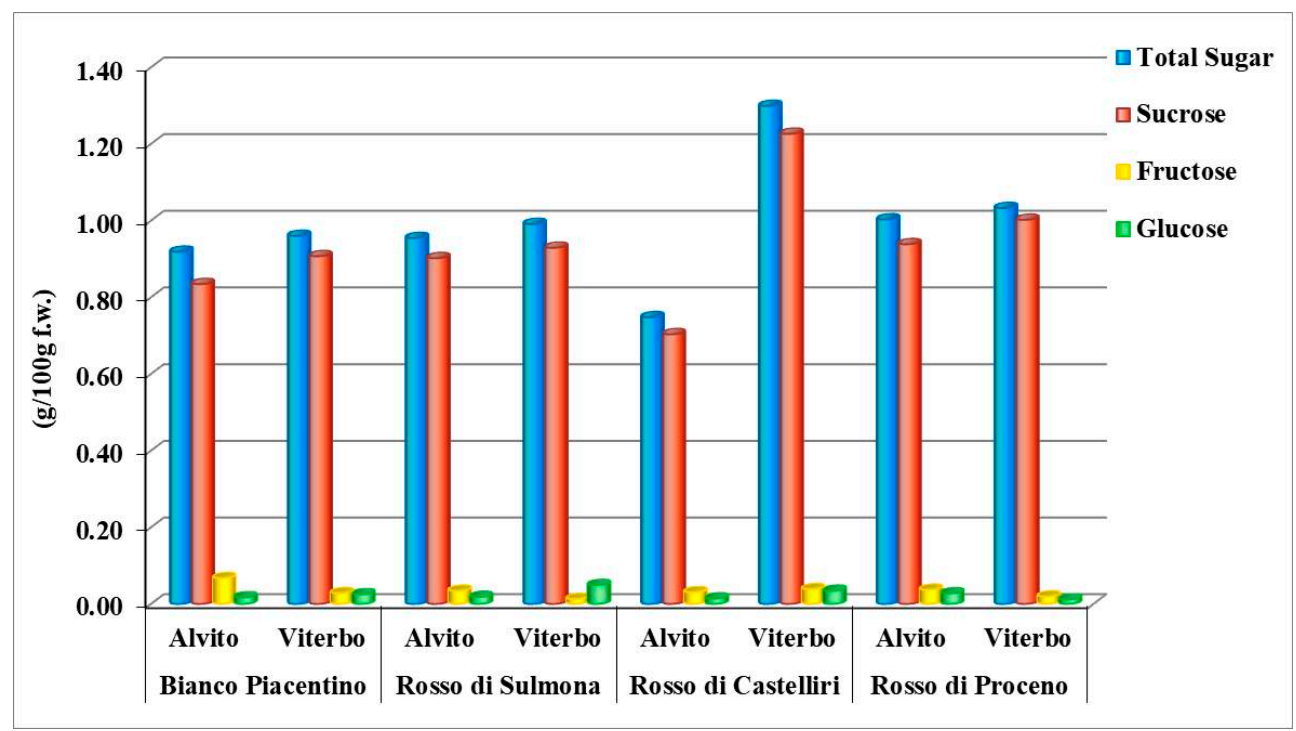

Figure 4. Total and individual sugar content in four garlic landraces. 
The results obtained from the measurements of the total carbohydrate components (mean and standard deviation) present in each of the four local garlic landraces were reported in Table 4 , taking into account both the variety and the cultivation area.

Table 4. Available and unavailable carbohydrates (g/100 g d.w.) in four garlic landraces from the Viterbo and Alvito areas *.

\begin{tabular}{|c|c|c|c|c|c|c|}
\hline \multicolumn{2}{|c|}{ Carbohydrates } & \multirow{2}{*}{$\begin{array}{c}\text { Area } \\
\text { Viterbo } \\
\text { Alvito }\end{array}$} & $\begin{array}{c}\text { Bianco } \\
\text { Piacentino }\end{array}$ & $\begin{array}{l}\text { Rosso di } \\
\text { Sulmona }\end{array}$ & $\begin{array}{l}\text { Rosso di } \\
\text { Castelliri }\end{array}$ & $\begin{array}{l}\text { Rosso di } \\
\text { Proceno }\end{array}$ \\
\hline \multirow{4}{*}{ Available } & Starch & & $\begin{array}{l}\operatorname{tr} \\
\operatorname{tr}\end{array}$ & $\begin{array}{l}\operatorname{tr} \\
\operatorname{tr}\end{array}$ & $\begin{array}{l}\operatorname{tr} \\
\operatorname{tr}\end{array}$ & $\begin{array}{l}\operatorname{tr} \\
\operatorname{tr}\end{array}$ \\
\hline & \multirow{2}{*}{ Total Sugars } & Viterbo & $2.42 \pm 0.20^{a}$ & $2.53 \pm 0.20^{\mathrm{a}}$ & $3.27 \pm 0.43^{b}$ & $2.68 \pm 0.34^{a b}$ \\
\hline & & Alvito & $2.66 \pm 0.29^{b}$ & $2.47 \pm 0.25^{\mathrm{ab}}$ & $2.12 \pm 0.11^{a}$ & $2.49 \pm 0.18^{a b}$ \\
\hline & & $p$-value $\S$ & n.s. & n.s. & $p<0.05$ & n.s. \\
\hline \multirow{6}{*}{ Unavailable } & \multirow{2}{*}{ Fructans } & Viterbo & $54.4 \pm 11.19$ & $49.7 \pm 8.40$ & $45.8 \pm 3.70$ & $49.6 \pm 2.80$ \\
\hline & & Alvito & $51.2 \pm 4.50$ & $47.2 \pm 6.10$ & $49.5 \pm 4.10$ & $46.3 \pm 2.80$ \\
\hline & & $p$-value ${ }^{\S}$ & n.s. & n.s. & $p<0.05$ & n.s. \\
\hline & \multirow{3}{*}{$\begin{array}{c}\text { Total dietary } \\
\text { Fibre }\end{array}$} & Viterbo & $13.1 \pm 1.50^{c}$ & $10.5 \pm 0.40^{\mathrm{ab}}$ & $9.1 \pm 0.90^{\mathrm{a}}$ & $12.1 \pm 0.30^{b c}$ \\
\hline & & Alvito & $11.7 \pm 2.00$ & $10.0 \pm 1.40$ & $11.4 \pm 1.20$ & $9.8 \pm 1.20$ \\
\hline & & $p$-value $\S$ & n.s. & n.s & n.s & $p<0.05$ \\
\hline
\end{tabular}

${ }^{*}$ Data are expressed as Mean \pm Standard Deviation. Anova, Tukey's honestly significant difference (HSD) Test: by

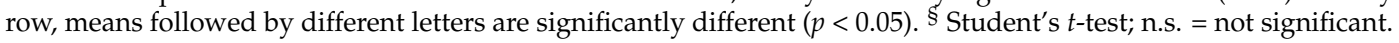

This includes available carbohydrates (starch and total sugars) and unavailable carbohydrates (fructans and dietary fibre). The values of available carbohydrates, when necessary to know the energy intake, were calculated as the sum of total soluble sugars and starch, and expressed as monosaccharides (conversion factor for starch $=1.1$ ) [40].

Starch was present, but in very low contents; its values were detected, indeed, but identified only in traces (amount $<0.06 \mathrm{~g} / 100 \mathrm{~g}$ f.w.) according to Darbyshire and Henry [57]. Although starch is generally the most widespread carbohydrate reserve in the plant kingdom, a storage function is attributed to the fructans present in the bulb tissues; these compounds may have some advantages compared with starch since they are resistant to cold, while the starch biosynthesis dramatically decreases when the temperature drops below $10^{\circ} \mathrm{C}$ [58].

Table 4 shows fructan contents to be the most representative component in all the garlic samples, comprising about $78 \%$ of the total carbohydrates, and varying from 45.8 to $54.4 \mathrm{~g} / 100 \mathrm{~g}$ d.w. These data were in agreement with values reported by Muir et al. [32], but higher than those reported by Peshev and Van den Ende [59], where the dietary fibre content accounted for 16-19\% of total carbohydrates.

Statistical analysis revealed that the fructan contents were never influenced by cultivar. No significant differences were observed regarding the effect caused by the cultivation area. Although samples from Viterbo exhibited higher values, only Rosso di Castelliri garlic showed a fructan content higher in samples coming from Alvito than in those grown in Viterbo. Ritsema and Smeekens [60] described how changes in fructan accumulation appear to have a role in the tolerance of some plant species exposed to environmental stresses; moreover, Van den Ende et al. [61] underline that the fructan content seems to be involved in osmoregulation in plants exposed to water restriction or low temperatures during certain periods of the year.

Regarding fructan, it was remarkable to consider that the Megazyme Assay Kit, which was used to quantify the total levels of fructan, does not provide information on the percentage of FOS and inulin, as reported by studies using other methods [32].

All of the samples were found to be a good source of total dietary fibre (Table 4), which ranged from 9.1 to $13.1 \mathrm{~g} / 100 \mathrm{~g}$ d.w.; in particular, in bulbs produced in Viterbo, the dietary fibre content varied among cultivars, whereas no significant difference was found between the bulbs from Alvito. The cultivation area did not affect the dietary fibre content except for Rosso 
di Proceno $(p<0.05)$. The dietary fibre content was higher than the average values observed in Italian commercial samples (about $7 \mathrm{~g} / 100 \mathrm{~g}$ d.w.) present in CREA's Food Composition Database [62], and those reported in USDA [63] (3.4/100 g d.w.); moreover, they are in line with values reported by Haciseferogullary et al. [64] for raw garlic grown in Turkey. These results highlight the added value of these Italian local garlic landraces.

Total sugars contents showed variability by cultivar: total sugars ranged from 2.42 to $3.27 \mathrm{~g} / 100 \mathrm{~g}$ d.w. in Viterbo samples, and from 2.12 to $2.66 \mathrm{~g} / 100 \mathrm{~g}$ d.w. in those coming from Alvito, which are values that are comparable with the average data present in the United States Department of Agriculture (USDA) Nutrient Database [63]. A significant difference $(p<0.05)$ was observed for the total sugar content in Rosso di Castelliri between Viterbo and Alvito samples.

In Table 5, the distribution of the sugar profile (glucose, fructose, sucrose) of the four local garlic landraces from two growing locations is reported.

Table 5. Profiles of total sugar (glucose, fructose, and sucrose) (g/100 g d.w.) in four garlic local landraces from the Viterbo and Alvito cultivation areas *.

\begin{tabular}{|c|c|c|c|c|c|}
\hline & Area & $\begin{array}{c}\text { Bianco } \\
\text { Piacentino }\end{array}$ & $\begin{array}{l}\text { Rosso di } \\
\text { Sulmona }\end{array}$ & $\begin{array}{l}\text { Rosso di } \\
\text { Castelliri }\end{array}$ & $\begin{array}{l}\text { Rosso di } \\
\text { Proceno }\end{array}$ \\
\hline Glucose & $\begin{array}{c}\text { Viterbo } \\
\text { Alvito } \\
p \text {-value }\end{array}$ & $\begin{array}{c}0.06 \pm 0.01^{\mathrm{b}} \\
0.05 \pm 0.01^{\mathrm{a}} \\
\text { n.s. }\end{array}$ & $\begin{array}{c}0.13 \pm 0.02^{\mathrm{d}} \\
0.05 \pm 0.01^{\mathrm{a}} \\
p<0.01\end{array}$ & $\begin{array}{c}0.09 \pm 0.01^{\mathrm{c}} \\
0.04 \pm 0.01^{\mathrm{a}} \\
p<0.01\end{array}$ & $\begin{array}{c}0.03 \pm 0.00^{\mathrm{a}} \\
0.07 \pm 0.01^{\mathrm{b}} \\
p<0.01\end{array}$ \\
\hline Fructose & $\begin{array}{c}\text { Viterbo } \\
\text { Alvito } \\
p \text {-value } \S\end{array}$ & $\begin{array}{c}0.07 \pm 0.01^{b} \\
0.20 \pm 0.03^{b} \\
p<0.01\end{array}$ & $\begin{array}{c}0.03 \pm 0.00^{\mathrm{a}} \\
0.09 \pm 0.02^{\mathrm{a}} \\
p<0.05\end{array}$ & $\begin{array}{c}0.10 \pm 0.02^{\mathrm{c}} \\
0.09 \pm 0.01^{\mathrm{a}} \\
\text { n.s. }\end{array}$ & $\begin{array}{c}0.05 \pm 0.01^{\mathrm{ab}} \\
0.09 \pm 0.01^{\mathrm{a}} \\
p<0.01\end{array}$ \\
\hline Sucrose & $\begin{array}{c}\text { Viterbo } \\
\text { Alvito } \\
p \text {-value } \S\end{array}$ & $\begin{array}{c}2.18 \pm 0.24{ }^{\mathrm{a}} \\
2.42 \pm 0.26 \\
\text { n.s. }\end{array}$ & $\begin{array}{c}2.37 \pm 0.20^{\mathrm{a}} \\
2.34 \pm 0.26 \\
\text { n.s. }\end{array}$ & $\begin{array}{c}3.08 \pm 0.42^{b} \\
1.99 \pm 0.10 \\
p<0.05\end{array}$ & $\begin{array}{c}2.60 \pm 0.34 \mathrm{ab} \\
2.33 \pm 0.18 \\
\text { n.s. }\end{array}$ \\
\hline
\end{tabular}

${ }^{*}$ Data are expressed as Mean \pm Standard Deviation. Anova, Tukey's honestly significant difference (HSD) Test: by row, means followed by different letters are significantly different $(p<0.05)$; ${ }^{\S}$ Student's $t$-test; n.s. $=$ not significant.

In all of the samples, total sugars were represented almost exclusively by sucrose; its concentration (Table 5) showed the lowest $(1.99 \mathrm{~g} / 100 \mathrm{~g}$ d.w.) and the highest values $(3.08 \mathrm{~g} / 100 \mathrm{~g}$ d.w.) in the Rosso Castelliri cultivar, coming respectively from Alvito and Viterbo. A similar trend was reported by Cardelle-Cobas et al. [65] for dehydrated commercial samples. In most studies on garlic, the content of sugars was not reported, and the lack of data mainly concerns sucrose.

Glucose and fructose were found at lower quantities than those found for sucrose, with a range of $0.03-0.13 \mathrm{~g} / 100 \mathrm{~g}$ d.w. and $0.03-0.20 \mathrm{~g} / 100 \mathrm{~g}$ d.w., respectively. In garlic grown in Viterbo, the amount of glucose content varied in the four local landraces, as shown in the following decreasing order: Rosso Sulmona $>$ Rosso di Castelliri $>$ Bianco Piacentino $>$ Rosso di Proceno. However, among the samples from Alvito, the Rosso di Proceno variety achieved the highest values. Fructose content in Bianco Piacentino bulbs was higher in both growing locations.

Moreover, as shown in Table 5, glucose and fructose were greatly affected by the cultivation area for all cultivars, except the Bianco Piacentino for glucose and the Rosso di Castelliri for fructose. On the contrary, sucrose content did not appear to be influenced by the cultivation area, except in the Rosso di Castelliri cultivar $(p<0.05)$.

\section{Conclusions}

Our findings have revealed that even the carbohydrates of the four Italian varieties chosen for the study can be influenced, like other nutrients, by the genotype and the cultivation area, and that their individual components are differently affected by these factors. These traditional varieties can be considered a good source of dietary fibre and fructans, especially the Bianco Piacentino ecotype grown 
in Viterbo. Fructans, in particular, are a good opportunity to add value to the production of foods both in terms of innovation-combined with the protection of consumers' interest-and profitability for the food industry.

This research provides evidence for the importance of studying the interaction between genotype, environmental conditions, and nutrient composition, in order to define the specific properties of Italian garlic local landraces and their total quality.

Since the four garlic ecotypes are registered in the list of traditional Italian agri-food products published by the Italian Ministry of Agricultural, Food, and Forestry Policies (MiPAAF) [66] in 2016, our results wish to contribute to raising knowledge and awareness about the quality of local products-some of which are at risk of erosion-by means of highlighting their nutritional characteristics, as well as contributing to their rural development and the protection of biodiversity.

Acknowledgments: This research was supported by the Ministry of Agricultural, Food and Forestry Policies-"BIOVITA" Project. The authors thank Annalisa Lista for the linguistic revision and editing of manuscript.

Author Contributions: Luisa Marletta and Olindo Temperini conceived and designed the experiments; Silvia Lisciani, Loretta Gambelli, Cecilia Rossetti, Paolo Gabrielli, Altero Aguzzi performed the experiments; Silvia Lisciani, Alessandra Durazzo, Loretta Gambelli, Stefania Marconi and Emanuela Camilli analyzed the data; Silvia Lisciani, Loretta Gambelli, Cecilia Rossetti, Paolo Gabrielli, Altero Aguzzi contributed reagents/materials/analysis tools; Silvia Lisciani, Loretta Gambelli, Alessandra Durazzo and Luisa Marletta wrote the paper.

Conflicts of Interest: The authors declare no conflict of interest.

\section{References}

1. Angiosperm Phylogeny Group (APG). An update of the Angiosperm Phylogeny Group classification for the orders and families of flowering plants: AGP III. Biol. J. Linn. Soc. Lond. 2009, 161, 105-121.

2. Food and Agriculture Organization of the United Nations (FAO). The State of Food and Agriculture. Agricultural Trade and Poverty; FAO: Rome, Italy, 2005.

3. ISMEA. Il Mercato Dell'aglio Tendenze Recenti e Dinamiche Attese. 2014. Available online: www.ismeamercati.it/flex/cm/pages/ServeBLOB.php/L/IT/IDPagina/3977 (accessed on 18 June 2017).

4. Brandolini, V.; Tedeschi, P.; Cereti, E.; Maietti, A.; Barile, D.; Coisson, J.D.; Mazzotta, D.; Arlorio, M.; Martelli, A. Chemical and genomic combined approach applied to the characterization and identification of Italian Allium savitum L. J. Agric. Food Chem. 2005, 53, 7-14. [CrossRef] [PubMed]

5. Ali, M.; Thomson, M.; Afzal, M. Garlic and onions: Their effect on eicosanoid metabolism and its clinical relevance. Prostaglandins Leukot. Essent. Fatty Acids 2000, 62, 55-73. [CrossRef] [PubMed]

6. Wilson, E.A.; Demmig-Adams, B. Antioxidant, anti-inflammatory, and antimicrobial properties of garlic and onions. Nutr. Food Sci. 2007, 37, 178-183. [CrossRef]

7. Corzo-Martìnez, M.; Corzo, N.; Villaiel, M. Biological properties of onions and garlic. Trends Food Sci. Technol. 2007, 18, 609-625. [CrossRef]

8. Choque Delgado, G.T.; Tamashiro, W.M.S.C.; Pastore, G.M. Immunomodulatory effects of fructans. Food Res. Int. 2010, 43, 1231-1236. [CrossRef]

9. Zhou, X.F.; Ding, Z.S.; Liu, N.B. Allium vegetables and risk of prostate cancer: Evidence from 132,192 subjects. Asian Pac. J. Cancer Prev. 2013, 14, 4131-4134. [CrossRef] [PubMed]

10. Nair, S.S.; Gaikwad, S.S.; Kulkarni, S.P.; Mukne, A.P. Allium sativum constituents exhibit anti-tubercular activity in vitro and in RAW 264.7 mouse macrophage cells infected with Mycobacterium tuberculosis H37Rv. Pharmacogn. Mag. 2017, 13, S209-S215. [PubMed]

11. Nasiri, A.; Ziamajidi, N.; Abbasalipourkabir, R.; Goodarzi, M.T.; Saidijam, M.; Behrouj, H.; SolemaniAsl, S. Beneficial effect of aqueous garlic extract on inflammation and oxidative stress status in the kidneys of type 1 diabetic rats. Indian J. Clin. Biochem. 2017, 32, 329-336. [CrossRef] [PubMed]

12. Ziamajidi, N.; Behrouj, H.; Abbasalipourkabir, R.; Lotfi, F. Ameliorative effects of Allium sativum extract on iNOS gene expression and NO production in liver of Streptozotocin + Nicotinamide-induced diabetic rats. Indian J. Clin. Biochem. 2017, 1-7. [CrossRef] 
13. Banerjee, S.K.; Maulik, S.K. Effect of garlic on cardiovascular disorder-A review. Nutr. J. 2002, 1, 4-14. [CrossRef] [PubMed]

14. Peinado, M.J.; Ruiz, R.; Echavarii, A.; Aranda-Olmedo, I.; Rubio, L.A. Garlic derivative PTS-O modulates intestinal microbiota composition and improves digestibility in growing broiler chickens. Anim. Feed Sci. Technol. 2013, 181, 87-92. [CrossRef]

15. Amagase, H.; Petesch, B.L.; Matsuura, H.; Kasuga, S.; Itakura, Y. Intake of garlic and its bioactive components. J. Nutr. 2001, 131, 955-962.

16. Banerjee, S.K.; Mukherjee, P.K.; Maulik, S.K. Garlic as an antioxidant: The good, the bad and the ugly. Phytother. Res. 2003, 17, 97-106. [CrossRef] [PubMed]

17. Santhosha, S.G.; Jamuna, P.; Prabhavathin, S.N. Bioactive components of garlic and their physiological role in health maintenance: A review. Food Biosci. 2013, 3, 59-74. [CrossRef]

18. Diretto, G.; Rubio-Moraga, A.; Argandoña, J.; Castillo, P.; Gómez-Gómez, L.; Ahrazem, O. Tissue-specific accumulation of sulfur compounds and saponins in different parts of garlic cloves from purple and white ecotypes. Molecules 2017, 22, 1359. [CrossRef] [PubMed]

19. González, R.; Soto, V.; Sance, M.; Camargo, A.; Galmarini, C.R. Variability of solids, organosulfur compounds, pungency and health-enhancing traits in garlic (Allium sativum L.) cultivars belonging to different ecophysiological groups. J. Agric. Food Chem. 2009, 57, 10282-10288. [CrossRef] [PubMed]

20. Touloupakis, E.; Ghanotakis, D.F. Nutraceutical use of garlic sulfur-containing compounds. Adv. Exp. Med. Biol. 2010, 698, 110-121. [PubMed]

21. Lee, S.H.; Liu, Y.T.; Chen, K.M.; Lii, C.K.; Liu, C.T. Effect of garlic sulfur compounds on neutrophil infiltration and damage to the intestinal mucosa by endotoxin in rats. Food Chem. Toxicol. 2012, 50, 567-574. [CrossRef] [PubMed]

22. Liang, D.; Wang, C.; Tocmo, R.; Wu, H.; Deng, L.-W.; Huang, D. Hydrogen sulphide $\left(\mathrm{H}_{2} \mathrm{~S}\right)$ releasing capacity of essential oils isolated from organosulphur rich fruits and vegetables. J. Funct. Foods 2015, 14, 634-640. [CrossRef]

23. Koruri, S.S.; Banerjee, D.; Chowdhury, R.; Bhattacharya, P. Studies on prebiotic food additive (inulin) in Indian dietary fibre sources-Garlic (Allium sativum), wheat (Triticum spp.), oat (Avena sativa) and dalia (Bulgur). Int. J. Pharm. Sci. 2014, 6, 278-282.

24. Vijn, I.; Smeekens, S. Fructan: More than a reserve carbohydrate. Plant Physiol. 1999, 120, 351-359. [CrossRef] [PubMed]

25. Gupta, A.K.; Kaur, N. Carbohydrate Reserves in Plants—Synthesis and Regulation, 1st ed.; Elsevier Science: Amsterdam, The Netherlands, 2000; ISBN 0444502696.

26. De Oliveira, A.J.B.; Gonçalves, R.A.C.; Chierrito, T.P.C.; dos Santos, M.M.; de Souza, M.S.; Gorin, P.A.J.; Sassak, G.L.I.; Iacomini, M. Structure and degree of polymerization of fructooligosaccharides present in roots and leaves of Stevia rebaudiana (Bert.) Bertoni. Food Chem. 2011, 129, 305-311. [CrossRef]

27. Hendry, G.A.F.; Wallace, R.K. The origin, distribution, and evolutionary significance of fructans. In Science and Technology of Fructans; Suzuki, M., Chatterton, N.J., Eds.; CRC Press: Boca Raton, FL, USA, 1993; pp. 119-139.

28. Van den Ende, W. Multifunctional fructans and raffinose family oligosaccharides. Front. Plant Sci. 2013, 4, 247. [PubMed]

29. Orcutt, D.M.; Nilsen, E.T. The Physiology of Plants under Stress: Soil and Biotic Factors; John Wiley \& Sons: New York, NY, USA, 2000.

30. Lewis, D.H. Nomenclature and diagrammatic representation of oligomeric fructans-A paper for discussion. New Phytol. 1993, 124, 583-594. [CrossRef]

31. Baumgartner, S.; Dax, T.G.; Praznik, W.; Falk, H. Characterisation of the high-molecular weight fructan isolated from garlic (Allium sativum L.). Carbohydr. Res. 2000, 328, 177-183. [CrossRef]

32. Muir, J.G.; Shepherd, S.J.; Rosella, O.; Rose, R.; Barrett, J.Q.; Gibson, P.R. Fructan and free fructose content of common Australian vegetables and fruit. J. Agric. Food Chem. 2007, 55, 6619-6627. [CrossRef] [PubMed]

33. Singh, R.S.; Singh, R.P.; Kennedy, J.F. Recent insights in enzymatic synthesis of fructooligo-saccharides from inulin. Int. J. Biol. Macromol. 2016, 85, 565-572. [CrossRef] [PubMed]

34. Shoaib, M.; Shehzad, A.; Omar, M.; Rakha, A.; Raza, H.; Sharif, H.R.; Niazi, S. Inulin: Properties, health benefits and food applications. Carbohydr. Polym. 2016, 147, 444-454. [CrossRef] [PubMed]

35. Roberfroid, M.B. Introducing inulin-type fructans. Br. J. Nutr. 2005, 93, S13-S25. [CrossRef] [PubMed] 
36. Roberfroid, M.B. Prebiotics: The concept revisited. J. Nutr. 2007, 137, 830S-837S. [PubMed]

37. Seifert, S.; Watzl, B. Inulin and oligofructose: review of experimental data on immune modulation 1-4. J. Nutr. 2007, 137, 2563-2567.

38. Roberfroid, M.; Gibson, G.R.; Hoyles, L.; McCartney, A.L.; Rastall, R.; Rowland, I.; Wolvers, D.; Watztl, B.; Szajewska, H.; Stahl, B.; et al. Prebiotic effects: Metabolic and health benefits. Br. J. Nutr. 2010, 104, S1-S63. [CrossRef] [PubMed]

39. Zhang, N.; Huang, X.; Zeng, Y.; Wu, X.; Peng, X. Study on prebiotic effectiveness of neutral garlic fructan in vitro. Food Sci. Hum. Wellness 2013, 2, 119-123. [CrossRef]

40. Slavin, J. Why whole grains are protective: Biological mechanisms. Proc. Nutr. Soc. 2003, 62, 129-134. [CrossRef] [PubMed]

41. Leenen, C.H.M.; Dieleman, L.A. Inulin and oligofructose in chronic inflammatory bowel disease. J. Nutr. 2007, 137, 2572-2575.

42. Fedewa, A.; Rao, S.S.C. Dietary fructose intolerance, fructan intolerance and FODMAPs. Curr. Gastroenterol. Rep. 2014, 16, 370. [CrossRef] [PubMed]

43. Azzini, E.; Durazzo, A.; Foddai, M.S.; Temperini, O.; Venneria, E.; Valentini, S.; Maiani, G. Phytochemicals content in Italian garlic bulb (Allium sativum L.) varieties. J. Food Res. 2014, 3, 26-31.

44. Carnovale, E.; Marletta, L. Tabelle di Composizione Degli Alimenti-Aggiornamento 2000 Inran; EDRA: Milan, Italy, 2000.

45. Marletta, L.; Camilli, E. Biodiversità e Agroalimentare: Strumenti per Descrivere la Realtà Italiana; Banca Dati BIOVITA; Casa Editrice CRA-ex INRAN: Rome, Italy, 2013.

46. Greenfield, H.; Southgate, D.A.T. Food Composition Data: Production, Management, and Use, 2nd ed.; FAO: Rome, Italy, 2003.

47. McCleary, B.V.; Gibson, T.S.; Mugford, D.C. Measurement of total starch in cereal products by amyloglucosidase— $\alpha$-Amylase method: Collaborative study. J. AOAC Int. 1997, 80, 571-579.

48. Lee, Y.C. Carbohydrate Analyses with High-Performance Anion-Exchange Chromatography. J. Chromatogr. A 1996, 720, 137-149. [CrossRef]

49. Ruggeri, S.; Cappelloni, M.; Gambelli, L.; Nicoli, S.; Carnovale, E. Chemical composition and nutritive value of nuts grown in Italy. Ital. J. Food Sci. 1998, 10, 243-252.

50. McCleary, B.V.; Blakeney, A.B. Measurement of inulin and oligofructan. Cereal Foods World 1999, 44, $398-406$.

51. McCleary, B.V. Measuring Dietary Fibre. World Ingred. 1999, 50-53.

52. Lever, M. Colorimetric and fluorimetric carbohydrate determination with $p$-hydroxybenzoic acid hydrazide. Biochem. Med. 1973, 7, 247-281. [CrossRef]

53. Fanaei, H.; Narouirad, M.; Farzanjo, M.; Ghasemi, M. Evaluation of Yield and Some Agronomical Traits in Garlic Genotypes (Allium sativum L.). Annu. Res. Rev. Biol. 2014, 4, 3386-3391. [CrossRef]

54. Noorbakhshian, S.J.; Mousavi, S.A.; Bagheri, H.R. Evaluation of agronomic traits and path coefficient analysis of yield for garlic cultivars. Pajouhesh Sazandegi 2008, 77, 10-18.

55. Dhakulkar, N.D.; Ghawade, S.M.; Dalal, S.R. Effect of spacing and clove size on growth and yield of garlic under Akola conditions. Int. J. Chem. Stud. 2017, 5, 559-562.

56. Sachin, A.J.; Bhalerao, P.P.; Patil, S.J. Effect of organic and inorganic sources of nitrogen on growth and yield of garlic (Allium sativum L.) var. GG-4. Int. J. Chem. Stud. 2017, 5, 559-562.

57. Darbyshire, B.; Henry, R.J. Differences in fructan content and synthesis in some allium species. New Phytol. 1981, 87, 249-256. [CrossRef]

58. Pollock, C.J.; Jones, T. Seasonal patterns of fructan metabolism in forage grasses. New Phytol. 1979, 83, 9-15. [CrossRef]

59. Peshev, D.; Van den Ende, W. Fructans: Prebiotics and immunomodulators. J. Funct. Foods 2014, 8, 348-357. [CrossRef]

60. Ritsema, T.; Smeekens, S. Fructans: Beneficial for plants and humans. Curr. Opin. Plant Biol. 2003, 6, $223-230$. [CrossRef]

61. Van den Ende, W.; De Coninck, B.; Van Laere, A. Plant fructanexohydrolases: A role in signaling and defense? Trends Plant Sci. 2004, 9, 523-528. [CrossRef] [PubMed]

62. Marletta, L.; Camilli, E. Aggiornamento 2008 Food Composition Database of CREA. Available online: http:/ / nut.entecra.it/646/Tabelle_di_composizione_degli_alimenti.html (accessed on 5 June 2017). 
63. U.S. Department of Agriculture National Agricultural Research Service. USDA Food Composition Database for Standard Reference; Software developed by the National Agricultural Library: Beltsville, MD, USA, 2016.

64. Hacıseferoğulları, H.; Özcanb, M.; Demira, F.; Çalışıra, S. Some nutritional and technological properties of garlic (Allium sativum L.). J. Food Eng. 2005, 68, 463-469. [CrossRef]

65. Cardelle-Cobas, A.; Costo, R.; Corzo, N.; Villamiel, M. Fructo-oligosaccharide changes during the storage of dehydrated commercial garlic and onion samples. Int. J. Food Sci. Technol. 2009, 44, 947-952. [CrossRef]

66. Ministero Politiche Agricole Alimentari e Forestali (MiPAAF). Prodotti Agroalimentari Tradizionali. 2016. $16^{\circ}$ Revisione. Available online: https://www.politicheagricole.it/flex/cm/pages/ServeBLOB.php/L/IT/ IDPagina/10241 (accessed on 10 June 2017).

2017 by the authors. Licensee MDPI, Basel, Switzerland. This article is an open access article distributed under the terms and conditions of the Creative Commons Attribution (CC BY) license (http://creativecommons.org/licenses/by/4.0/). 